\title{
SAFETY OF COASTAL STRUCTURE AS A BREAK WATER STRUCTURE
}

\author{
N.R.K.Patnaik ${ }^{1}$, K. Anil Kumar ${ }^{2}$ \\ ${ }^{\text {I} M t e c h ~(s t u d e n t) ~ C i v i l ~ E n g i n e e r i n g ~ D e p a r t m e n t, ~ G i t a m ~ u n i v e r s i t y, ~ A n d h r a ~ P r a d e s h, ~ I n d i a ~}$ \\ ${ }^{2}$ Assistant professor, Civil Engineering Department, Gitam university, Andhra Pradesh, India
}

\begin{abstract}
Disaster is the serious disruption in the functioning of the society or community causing environment looses. Past cyclones effected marine structures (such as break waters, seawalls etc). Break water is a structure built to reduce wave action in Port area. Port's are gateway to country transport for cargo handling \& commodity. Break water structure protect port entrance channels on lee side \& harbor side of the port. The entrances to most of the ports are protected by rubble mound breakwater structure, the outer slopes of the break water structure have different Artificial an armour units(kolas, dollos, $x$-bloc etc) \& mass concrete. Reducing wave action in port, for the purpose of cargo handling. we are built break water structure as a safety structure in coastal areas.
\end{abstract}

Keywords: Rubble mound break water1, bulk heads 2, sea walls3.

\section{INTRODUCTION}

On The Basis Of Purposes there are different types of coastal structures.

\subsection{Break Water Structure}

Break water is a structure constructed on seashore to reduce wave action. It is a structure constructed for the purpose of forming artificial harbor with a basin. These are mostly built of quarried rock. Precast elements such as x-bloc, dolos, cubes, tetrapod etc (or) large armour stones are used to protect outer layer against waveattack.Breakwater are large scale structures constructed seaward of, \& usually to the shore line.

\subsection{Bulkheads}

Bulkheads are vertical retaining walls to hold or prevent the soil from sliding seaward. These reduce land erosion.

\subsection{Seawalls}

Sea walls are vertical structures constructed parallel along the shoreline. It can be used as soil retaining structure to protect shoreline from erosion against wave action \& currents. Seawalls may be vertical or sloping. Vertical seawalls can be provided marine for vessel berthing \& cargo handling.

\section{PORT}

Port is important in international trade. It is a place where vessels may discharge or receive cargo.

\subsection{Port Significance}

Ports are gateway to country transport for cargo handling \&
Commodity. These are facilities for berthing \& anchoring ships \& providing equipments for transfer of goods from shore to ship. The major commodities handled at port are containers, cargoes, coal, automobiles, iron ore etc.

Some imports are steam coal, fertilizers, lamcoke etc

\section{2 layout of Port}

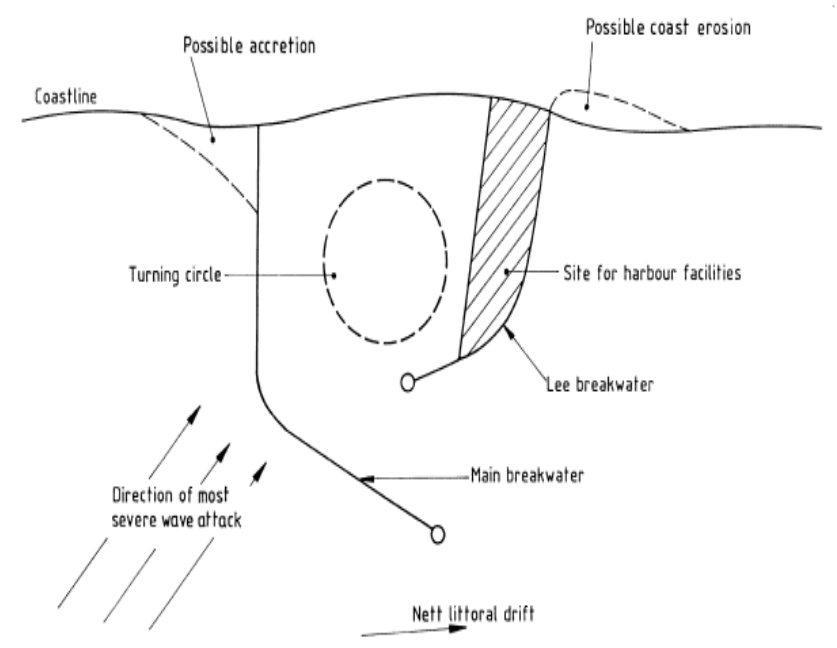

\section{BREAK WATER STRUCTURE}

It is a structure protecting a shore area, anchorage, harbor from the effects of weather and long shore drifts. Break waters are constructed in severe environments. These are constructed for the purposes of quiet water for anchorage or mooring of vessels. They attempt to break incoming waves before they reach to shoreline. 


\subsection{Types of Break water structure}

(a) Rubble mound break water

(b) Composite break water

\subsubsection{Rubble Mound Break Water}

Rubble mounds are frequently used structures. Rubble mound breakwater consists of armour layer, a filter layer \& core. It is a structure, built up of core of quarry run rock overlain by one or two layers of large rocks. Armour stone or precast elements are used for outer armour layer to protect the structure against wave attack. Crown wall is constructed on top of mound to prevent or to reduce wave overtopping. It requires large amount of material than others.

\subsubsection{Composite Break Water}

Composite break water consists of vertical wall \& rubble foundation. Concept of vertical break water is to reflect waves. While rubble mound break water is to break the waves. To reduce wave reflection \& breaking wave forces on vertical walls concrete blocks are placed on sea side. This type of structure constructed in very deep water.

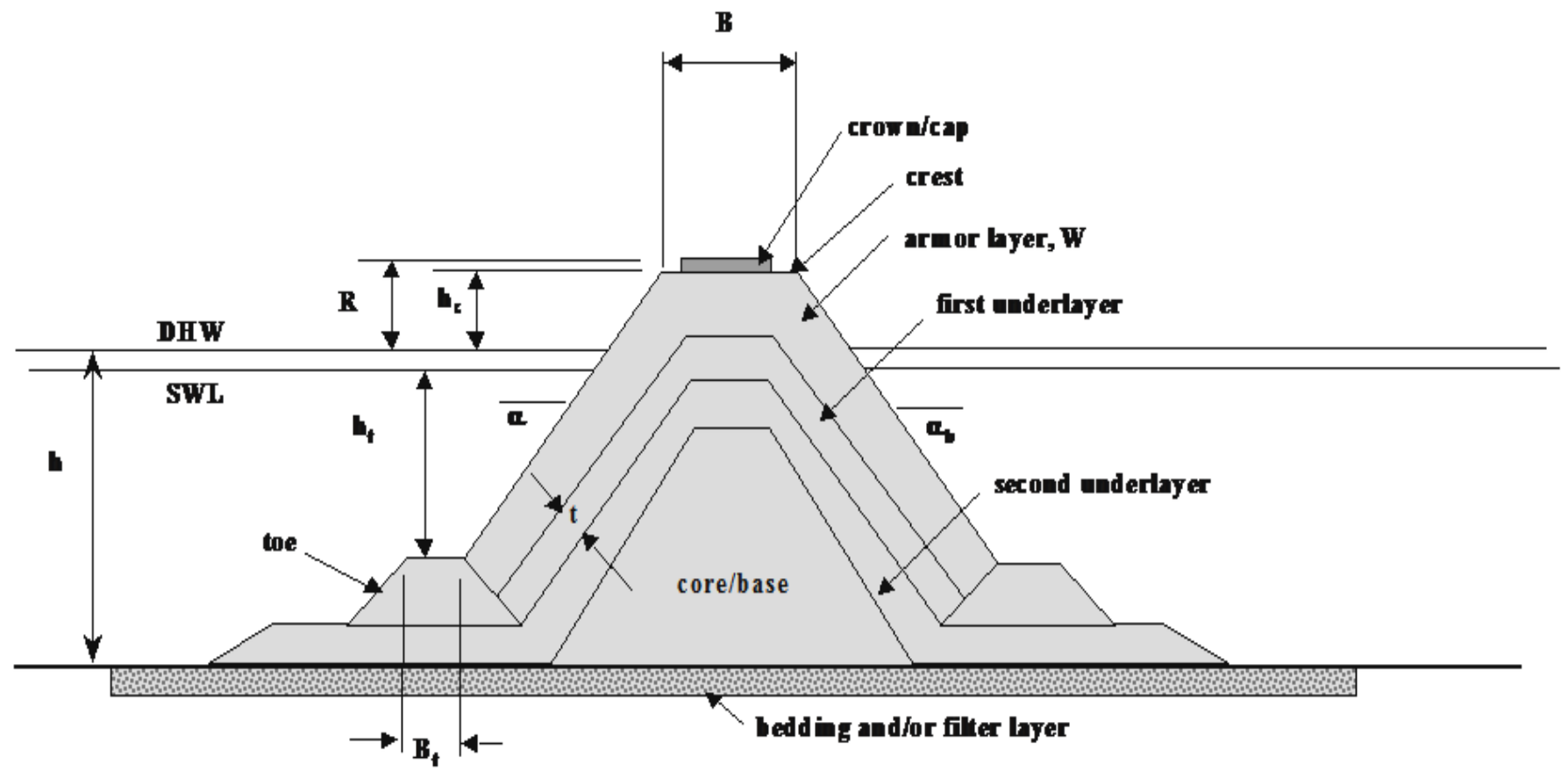

Fig 1: layout of rubble mound breakwater

\subsection{Selection of Break water structure}

Layout of break water

Operational conditions

Availability of construction materials

Construction cost

Navigation requirements

Environmental conditions

\section{GEOMETRIC OF RUBBLE MOUND}

\section{BREAKWATER STRUCTURE}

Core

Armour layer

Crown wall

Slope angle

Core: It is usually built of dredged or blasted material such as quarry run. Reuse of dredged material as a core is to reduce of cost \& quantity of material required. Core material is cheapest material.
Crown wall: A Superstructure consists of concrete cap block or wave wall.

Concrete caps: concrete caps are constructed to strengthen crest, increasing crest height, \& to maintenance purpose.

Slope angle: slope angle in the front face should be as steep as possible to minimize the volume of structure. Slope for artificial armour units are 1:1.5.

Armour layer: Armour units are used in seaward slope of rubble mound breakwater Armour layers are of two types one is rock another is artificial armour unit such as x-bloc, cube, and tetrapod etc.first choice of armoring is rock for economical \& possible reasons. Where rocks of sufficient size, quality, quantity is not available. Artificial armour units will be required.

A variety of concrete armour units has been developed in last 50years.breakwater armour units are rocks (or) cubes. Tetrapod was introduced in 1950, when compared to cube, 
tetrapod has more interlocking which causes wave energy dissipation, \& reduces wave run-up. A variety of concrete armour units are developed in 1950-1970 they have been applied for limited projects only.

Accropode as Single layer randomly placed armour units have been applied since 1980 for reducing cost \& quantity. Core loc, A-jack type armour unit are developed subsequently. These are high interlocking \& single layer random placement.

\section{CONCLUSION}

Protection of the ports \& harbours from the natural or manmade calamities such as cyclones or tsunamis is essential. But exact control of the natural calamities is not possible, but some extent it can be prevented by break water construction.

To protect our coastline from wave action or erosion, coastal structures are needed for safety.

\section{REFERENCES}

[1]. Text book of Construction of marine \& offshore structure by Ben c.Gerwick, jr.

[2]. Port engineering by liu,zhou :burchart, hans falk.

\section{BIOGRAPHIES}

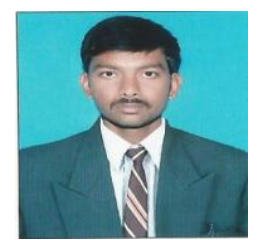

Mr.Nagumantri .R.K.Patnaik resident of Andhrapradesh received his bachelors degree in civil engineering from vitam college of engineering, He has worked with gkc projects ltd, and presently he is Master student in structural engineering $\&$ natural disaster management in Gitam university.

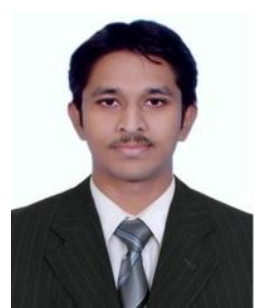

K.Anil kumar (assistant professor) received his mtech (structural engineering) from Acharya Nagarjuna University. he has also worked as design engineer in viswa vani engineers and presently he is assistant professor in Gitam university. 